International Peacekeeping

\title{
Peacebuilding: Understandings, Practice, and the Way Ahead
}

\section{Roberta Holanda Maschietto}

To cite this article: Roberta Holanda Maschietto (2018): Peacebuilding: Understandings, Practice, and the Way Ahead, International Peacekeeping, DOI: 10.1080/13533312.2018.1558401

To link to this article: https://doi.org/10.1080/13533312.2018.1558401

册 Published online: 27 Dec 2018.

Submit your article to this journal ๘

Џll Article views: 9

View Crossmark data ¿ 


\title{
Peacebuilding: Understandings, Practice, and the Way Ahead
}

\author{
Quality Peace. Peacebuilding, Victory, \& World Order, by Peter
} Wallensteen, Series Studies in Strategic Peacebuilding, New York, Oxford University Press, 2015, pp. 210 + notes + references + index, $£ 29.49$ (pbk), ISBN: 978-0-19-021555-2

Peacebuilding, the Twenty Years' Crisis, 1997-2017, Series Rethinking Peace and Conflict Studies, by David Chandler, Cham, Switzerland, Palgrave Macmillan, 2017, pp. 210 + references + index, £17.99 (pbk), ISBN: 978-3-319-50321-9

Peacebuilding has been a controversial topic. For starters, its meaning is far from consensual, definitions ranging from very narrow (e.g. directly linked to UN activities and covering a very short period of time), to broader understandings that encompass long term changes in relational dynamics and leading to reconciliation, as well as structural changes. A direct consequence of these different understandings is the different ways in which peacebuilding has been analysed in academia. The two books here reviewed reflect the multiplicity of this debate, offering different views about the current state of peacebuilding and its future.

Quality Peace. Peacebuilding, Victory, \& World Order, by renowned peace researcher Peter Wallensteen, represents an attempt to expand the debate on peace and peacebuilding by bringing different strands of the literature together as well as by offering a new concept through which to analyse post-war conditions - quality peace. Wallensteen maintains that 'the postwar condition of any relationship has to be dealt with between the parties and placed on a national as well as international agenda' (2). Peacebuilding strategies - or strategic peacebuilding - would play an important role in the design and implementation of peace agreements. Yet, peacebuilding would be only one of the possible outcomes, the other one, much less discussed, being victory consolidation.

Focusing on the features of the peace that follows the end of a war, Wallensteen introduces the concept of quality peace, depicted as a 'concept for breaking out of the dichotomy of negative versus positive peace that long has been taken for granted. It simply says that peace has to have a particular quality beyond the absence of war' (3). If peace does not last, that is because it did not meet the quality standards of peace. More generally, quality peace is a relational concept, concerning primarily the formerly warring parties, but extending also to populations within the society at large, as well as to inter-societal relations 
(17). In this book, three specific qualities are tested: dignity, security and predictability. These qualities are chosen because together they 'draw attention to the quality of the relationships following a war and the regulation of the disagreements that led to the war' (6).

The book is structured in 8 chapters, including the introduction and a brief conclusion that sets out the paths to quality peace. Chapter 2 offers a review of the existing literature on peace and post-war conditions (largely based on the discussion on peacebuilding), as well as victory and world order. Chapter 3 to 7 focus on different settings where to assess quality peace. Chapters 3, 4 and 5 deal with different types of violent conflict and the peace that follows, specifically civil wars, state formation conflicts and interstate conflicts. Chapters 6 and 7 then assess the actual and potential contribution of the world order and international organizations to promote quality peace at the scale of any given conflict.

One of the added values of this book is Wallensteen's effort in bringing together literature that usually stands in different library shelves. On the one hand, he deals with the existing and heterogeneous literature on peacebuilding; on the other hand, he engages with the literature on victory and victory consolidation. By looking and this expanded view of peace outcomes, Wallensteen relies on the Uppsala Conflict Data Program (UCPD) database, as well as several specific cases, to assess situations of peacebuilding and victory while asking whether the peace that follows meet the criteria of quality peace (and which of the scenarios is more prone to produce quality peace). While there is an emphasis on cases that took place after the end of the Cold War (as it is usually the case in the peacebuilding literature), Wallensteen goes back to the Cold War and the immediate post-World War II in order to assess the extent to which this particular change in the world order has affected the preferred options for peacebuilding or victory and why.

The conclusions overall supports the hypothesis that negotiated outcomes (i.e. peacebuilding) are better suited to provide quality peace outcomes, as compared to victory scenarios. This is particularly so in the case of post-civil war situations, whereas results are more mixed in the case of state formation conflict. As to interstate post-war peacebuilding (an idea that would seem odd in most of the peacebuilding literature), Wallensteen notes that there are not enough cases to rely on and from which to build generalizations. Still, the two cases analysed (France and Germany after World War II - which could be regarded as victory consolidation but which entailed the creation of a different reality aimed at preventing the recurrence of war - and Ecuador-Peru since the mid-1990s) suggest that more space for cooperation derives from a clear negotiated territorial settlement, and that the existence of democratic institutions of both sides highly influence the cooperative outcome.

The breadth of Quality Peace is remarkable. Besides navigating through an enormous and diverse theoretical literature, Wallensteen provides an extensive comparative analysis, building mostly on statistical comparison using the classification and data of the UCPD, as well as including the analysis of cases that were left out or that were no comparable due to the lack of enough or similar data. The proposition that victory outcomes need to be taken into consideration in the 
analysis of peace seems particularly relevant at this historical moment when conservative political forces are moving away from peacebuilding strategies.

Notwithstanding the clear contribution of the book to better understand peace, I would like to highlight three elements that would benefit from further reflection. First, whereas quality peace is provided as an alternative to move away from the dichotomy negative/positive peace, it is not that clear that it does so. Clearly quality peace is not simply negative peace, since it entails specific qualities that go beyond the mere cessation of direct violence. But how different is quality peace from positive peace? One of the aspects seems to be the fact that there is not a predetermined list of qualities, as stated early in the book (6). Yet, it could be argued that the three elements used to assess quality peace (security, dignity and predictability) could easily related to the more general idea of positive peace. In practical terms, even positive peace can be measured in a scale instead of being an absolute state of affairs, as long as clear criteria are defined (an exercise seen in the case of the Positive Peace Index).

A second aspect that is not very clear is the domain of predictability, that is, the idea that conflict will not resume in the 'foreseeable future', one of the elements assessed in quality peace. Wallensteen admits that the notion of foreseeable future is not strict, since 'the time horizons are likely to be different for leaders and for society' (65). Generational aspects count, as well as the duration of regimes and leaders. It is indeed clear that a very short timespan (e.g. two years, or even five, as often used in policy) is not enough to assess the quality of peace, but how long is the time span is not clear. In fact, we can make a parallel with the problems related to the assessment of positive peace and the difficulties in confirming its actualization. For Wallensteen, if a conflict starts again or resume, even if many years later, then there was no quality peace, but perhaps an inter-war period. But how can we grasp this possibility beforehand or even afterwards (or how long afterwards)? This is not clear in the book.

A third aspect to be considered is that, while briefly referencing the work of Roger Mac Ginty and Oliver Richmond there is very little engagement with the critical literature on peacebuilding, more specifically the so called 'local turn' in peacebuilding. Interestingly, Wallensteen acknowledges that the three main types of literature he engages with - i.e. the actor-oriented approach that focus on peacebuilding as missions and policies, the systemic approach that focuses on quantitative studies, and the structural approach that deals with the recurrence of war - hardly intersect, even though they all contribute to a more comprehensive peace research perspective. It is fair to say that dealing with this enormous amount of literature would require a much larger book. However, several times Wallensteen refers to the relevance of local capacity and goes back to the work of Doyle and Sambanis, while leaving aside a huge amount of material that dissects issues of empowerment, participation and emancipation as well as local ownership precisely in the context of peacebuilding. This literature could definitely contribute to the understandings of dignity, security and predictability, which are at the core of quality peace. That said, Wallensteen himself admits that this study is a starting point for something bigger to be developed. In fact, a new 
book has been released in 2018 (while I write this review), presenting several case studies alongside the proposition of additional dimensions of quality peace.

It is important to highlight that Wallensteen has very practical concern: he is clearly interested with the concrete possibilities to foster quality peace. In other words, the comparisons and case studies are meant to provide insights to further inspire action at the international level so sustainable peace can be promoted. In this regard, the book is fairly optimistic about the concrete possibilities for peace promotion and about peacebuilding, understood as a negotiated peace.

In contrast, David Chandler's Peacebuilding, the Twenty Years' Crisis, 19972017 sets a very different tone to the peacebuilding debate. For starters, peacebuilding is understood in a much more specific way, 'as a field of external policy intervention with the intention of assisting post-conflict or conflictprone states to build a sustainable peace on the basis of liberal institutional frameworks of constitutionalism, market freedoms, democracy and the rule of law' (3). In this regard, it engages more directly with the peacebuilding literature dealing with the 'liberal peace'.

Also, differently from Wallensteen, the purpose is not to make a survey of peacebuilding missions or states of peace, but rather to grasp 'the changes in the understanding of the peacebuilding project itself (3). Borrowing from E. H. Carr's classic book The Twenty Years' Crisis, Chandler stresses the competing discourses underlying the peacebuilding project and how it started as a liberal (perhaps utopian) project, 'ending up in a 'realist' or pragmatic mode of resignation and disillusionment' (4). It sets, therefore, a more pessimistic tone, marking the actual 'end of peacebuilding' as the policy agenda moves towards a more pragmatic approach that aspires not to transform and 'build' peace, but instead to 'facilitate' local solutions to concrete problems.

The book is structured in five parts, four of them with two chapters each, the last one with a conclusion. The first part presents the book and discusses the pragmatic critique that informs peacebuilding presently. A central argument is that the interpretation that peacebuilding has been driven by liberal values (as has been discussed extensively in the literature) is a fallacy. First, the use of the term 'liberal' bares little relation with the classic concept. Secondly, while the critical discourse reinforced the idea that peacebuilding was a liberal project aiming at imposing/exporting Western values elsewhere, this did not reflect what was going on in terms of policy practice. Instead, Chandler argues that 'post-Cold War postconflict intervention and peacebuilding can better be understood as reflecting disillusionment with classical liberal assumptions about the autonomous subject framed in terms of sovereignty, law, democracy and the market' (21). The 'rise of peacebuilding' was, thus, the result of revision of a state-centred approach to a people- or human-centred one that legitimated intervention in the domestic political realm.

The crisis of peacebuilding eventually started because of the excessive confidence (or the 'hubris') in the effectiveness of those interventions, reflected in the creation of a permanent protectorate in Bosnia-Herzegovina in 1997 and later in Kosovo and Timor-Leste. Those experiments showed the contradictions and limits of external rule and paved the way for the transformation of 
peacebuilding into statebuilding. Statebuilding was thus a reaction to the failures of excessive intervention, and provided an attempt for internationals to retreat from such a burden and shift back responsibility to the people and societies of the states target of peacebuilding. At the same time, whereas the argument sustaining statebuilding was that it was a means to strengthen sovereignty by helping building functional institutions and good governance, it was in fact an exercise that 'resulted in the institutionalisation of weak states which had little relationship with their societies and lacked legitimate authority' (69). This contradiction led to an impasse in peacebuilding, where internationals tried to eschew their responsibilities - and shifting them to domestic actors - while at the same time trying to impose or develop liberal institutional frameworks. This, in turn, only reinforced the gap between the 'internationals' and the 'locals', as exemplified in the case of Bosnia and the policies aimed at building civil society and the rule of law, explored in the third part of the book.

The fourth part of the book turns to the attempts to move beyond this impasse. Firstly, Chandler addresses the 'turn to the local', understood as a shift away from linear understandings of peacebuilding. He notices that, while offering important critiques to peacebuilding, these approaches also reified the idealist understanding of international peacebuilding because they focused on the inter-subjective dimension of the local as main reason to explain hybrid/non-liberal outcomes. That is, the emphasis was on the cultural and cognitive levels, while minimizing the social and economic context. A derivation of this was the entrenchment of a binary vision that reinforced the 'West' versus the 'local', and a shift to a new kind of intervention that focused on society instead of the political realm. The further turn to the concept of resistance and hidden transcripts eventually contributed to the abandonments of the transformative aspiration of peacebuilding, based on the idea that there was a clear limit on the extent to which external actions could influence social change in peacebuilding settings.

Moving away from this impasse eventually became possible through the resilience approaches to intervention. As Chandler highlights, these approaches focus on the local context, but present a more pragmatic quality stressing the role of concrete social practices. A major difference between the 'local turn' and the resilience approaches is their starting point: whereas the former understand the local in opposition to the 'liberal' peace, stressing the role of cultural differences, the latter has roots in the study of everyday practices that provide solution to concrete issues. There is no concern with resistance, opposition or cultural relativism, only a very direct concern with practical and functional problem-solving. Influenced by philosophical pragmatism, this pragmatic approach 'evaded the problems of the "liberal" discourses of peacebuilding, neither imposing a universal framework over sociocultural difference, nor recognising or privileging 'local' choices as emancipatory' (181).

If overcoming the peacebuilding impasse seems a positive thing, Chandler also notes that this approach 'did little to enable the broader structural and socioeconomic context of decision-making to come under consideration while the shift of interventionist policymaking from the public sphere of constitutionalism and law did little to clarify accountability for policymaking' (187). In this frame, all 
problems and solutions are located at the local level; there is the removal of the big picture. It does not solve, therefore, the big problems of asymmetries and inequality.

The conclusion stresses 'the end of the liberal episteme', an episteme that reflects a broader modernist understanding of causality, reflecting, thus, a change in the very understanding of what peacebuilding is or should be. In practice, this means that there is less concern now with prevention and conflict resolution, but more interest in conflict management. Conflict has to be 'coped' with, meaning that state-level intervention is now regarded as having limited use.

Overall, Chandler's provides a very comprehensive review of the state of the art of the peacebuilding debate, while convincingly reinterpreting key narratives and questioning several assumptions that have been part of the 'liberal peacebuilding' debate, not least the 'liberal' feature of peacebuilding. After reaching the end of the book, however, one can't help but wonder, 'what's next?' The decree of the end of peacebuilding as a political project and the assessment that the pragmatic approach does not necessarily constitute a move forward leads to a hint of nostalgia and disillusionment with the very idea of promoting peace. The highlights of the 'twenty years' crisis' - a crisis that started shortly after peacebuilding became an international political project - do not leave room for optimism. On the contrary, it is the repetition of failure that leads to the constant shifts in the agenda. The picture, therefore, is far from optimistic and sharply contrasts to the assessment of Wallensteen, who, while not addressing the future of peacebuilding per se, points to the benefits of peacebuilding (defined in different terms) as a means to promote quality peace. These different views reflect how different understandings of peacebuilding - as well as the different timeframes and methodologies - may lead to different conclusions.

Beyond these differences, however, both books also share some parallels. One of the elements often stressed in Peacebuilding, the Twenty Years' Crisis is that socio economic aspects matter and yet they have been overlooked in several instances of the peacebuilding debate and practice. Wallensteen clearly refer to the need of approaching development and economic matters in the analysis of peace and the concept of quality peace places an effort in bridging this dimension with other more commonly referred to, such as security and legitimacy. Concerns with international asymmetries and inequalities have been expressed in the literature on peacebuilding, but this is a topic that needs further exploration.

Another element that approximates both books, albeit expressed in different ways, is the concern with multiple levels of analysis. This is perhaps one of the most challenging exercises when it comes to peace and conflict, not least because local and global dynamics may seem often too disconnected to be related. Also, there are different ways through which we may think of levels, the complex discussion about the 'local' (and 'local-local') being an example. Both Chandler and Wallensteen engage with multiple levels of analysis, Wallensteen being particularly concerned with the study of the world order as an element affecting peace within states, and Chandler pointing to the very practical effects of the shift of the international agenda in peacebuilding implementation in Bosnia. 
They offer different ways to do this exercise, but both remind us of how relevant that is.

A final note relates to an element that has to be better explored in the analysis of peacebuilding - the subjective domain. This is not discussed in Quality Peace and appears in Chandler's book in the context of the discussion of the 'local turn' but is not developed further. Whereas in the 'local turn' there has been an obvious concern with culture and issues of identity, as noted by Chandler, the emphasis has remained largely in the domain of resistance and opposition to the 'West' or the 'liberal'. The extent to which culture, subjectivities and identity relate to attitudes as well as material aspects (such as the distribution of material assets in a society) has yet to be explored in the analysis of peacebuilding. The work of Bourdieu could be used as a starting point for this exercise. Perhaps this should be the next step in the analysis of peacebuilding.

Roberta Holanda Maschietto

Centre for Social Studies, University of Coimbra, Coimbra, Portugal (2hmaschietto@gmail.com (1) http://orcid.org/0000-0002-6079-280X

(c) 2018 Roberta Holanda Maschietto https://doi.org/10.1080/13533312.2018.1558401 